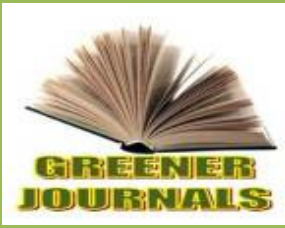

\title{
Biomass Yield and Biological Potential of Grass (Chloris gayana) and Legume (Medicago sativa) Mixtures under Variable Seed Rates in Southern Region of Ethiopia
}

\author{
Mergia Abera
}

Southern Agricultural Research Institute, P.O Box 6, Hawassa, Ethiopia.

Article No.: 080817102

DOI: 10.15580/GJAS.2017.6.080817102

Submitted: 08/08/2017

Accepted: 10/08/2017

Published: 22/08/2017

${ }^{*}$ Corresponding Author

Mergia Abera

E-mail: aberamergiya @yahoo

.com

Keywords:

Forage yield, Biological Potential,

Chloris gayana, Medicago sativa

and mixtures
The study was conducted at Hawassa Agricultural Research Center in Ethiopia to determine the optimum seed rate proportion of mixtures of Chloris gayana (CG) and Medicago sativa (MS) for obtaining higher dry matter yield (DM) from the mixtures. CG and MS were planted as pure stand and in mixtures using $75 \%(C G)+$ $25 \%(\mathrm{MS}), 50 \%(\mathrm{CG})+50 \%(\mathrm{MS}), 25 \%(\mathrm{CG})+75 \%(\mathrm{MS}), 0 \%(\mathrm{CG})+100 \%(\mathrm{MS})$ and $100 \%(\mathrm{CG})+0 \%(\mathrm{MS}), 100 \%(\mathrm{CG})+25 \%$ (MS) and $100 \%(\mathrm{CG})+50 \%(\mathrm{MS})$ seed rate proportion in a randomized complete block design with three replications. There were significant $(P<0.05)$ differences in the crud protein and lignin of the grass components among the grass/legume combinations due to seed rate proportions. Not significant $(P>0.05)$ effects were observed on the $D M$, the relative yield (RY) and the relative total yield (RTY). However; the 50:50\% mixture gave higher DM yield and had the highest RTY than other mixtures. From this result, it is concluded that $50: 50 \%$ mixture was found to be the optimum seed rate proportion to develop a balanced grass-legume mixture. In addition, further studies need to be undertaken under varying environments and harvesting strategies. 


\section{INTRODUCTION}

Livestock plays a crucial role in the smallholder farming systems of Ethiopian agriculture. Currently, productivity per animal is very low, and the contribution of the livestock sector to the overall economy is much lower than expected. A major constraint to the livestock industry is feed inadequacy. Both under-nutrition and malnutrition are major problems for the greater part of the country and for most of the time (Lulseged, 1985). Livestock depends on natural pastures and crop residues and both the quantity and the quality of these feedstuffs are too low to sustain satisfactory levels of animal production.

According to survey reports of Raya (1988) and Getahun, et al., (1991), livestock feed shortage is the principal problem of smallholder farmers in Sidama and South Omo zones of the Southern region. The main feed source for the Livestock is natural pasture, which is low in herbage yield and nutrient value.

In Hawassa Agricultural Research Center several lines of grasses and legumes have been tested in past few years and some species have shown promising indication in terms of adaptation, productivity and acceptance by farmers. From tested perennial grass varieties Chloris gayana and from legumes Medicago sativa were selected for forage use in the region (Mergia, 2002).

Integration of grass/Legume mixture is one of the approaches to solve inadequate feed quality and quantity. Forage legumes improve soil fertility, grass yields and herbage quality and make the system more sustainable. Results of research works in tropics (Daniel, 1990; Lemma et al, 1993) have indicated that grass and legumes mixtures significantly contribute to total herbage yield and quality. The dry matter and animal output from reinforced by legumes was found to be promising (Lemma et al 1993) in sub-tropics area. Although grass and legume can each be grown in pure stand, growing them in mixtures produce higher yield \& quality forage (Daniel, 1989).

Other advantages of grass-legume mixtures include (1) excellent energy \& protein balance for ruminants (Daniel, 1989); (2) improve drying or caring quality of mixture (Droson, 1976); (3) excellent soil conserving restoration feature of grass and Legume respectively, best yield mixture (Rhodes, 1970); vary with the species utilized, the environment and with the management (Rhades, 1970).

Development of grass and Legumes mixed pasture is one of recognized strategies for enhancing the quality and quantity of feed resource. Therefore, to establish a balance grass and legume mixed pasture and determination of an optimum seed proportion was indispensable. The objective of this study was to determine optimum seed proportion of Chloris gayana and Medicago sativa for the development balanced \& productive mixture.

\section{MATERIALS AND METHODS}

\section{Descriptions of the test environment}

The experiment was conducted at Hawassa Agricultural Research Center during the main cropping seasons. The test location represents the midland areas of Ethiopia. The farming system of the study area is mixed crop livestock production system. Descriptions of the test environment are indicated in Table 1.

Table 1: Descriptions of the test environments for geographical position and physico-chemical properties of

\begin{tabular}{|l|l|l|}
$\mathbf{S N}$ & Tarameter & Hawassa \\
\hline $\mathbf{1}$ & Latitude & $7^{\circ} 04^{\prime} \mathrm{N}$ \\
\hline $\mathbf{2}$ & Longitude & $38^{\circ} 31^{\prime} \mathrm{E}$ \\
$\mathbf{3}$ & Altitude (masl) & 1700 \\
\hline $\mathbf{4}$ & Distance from Addis Ababa $(\mathrm{km})$ & 275 \\
\hline $\mathbf{5}$ & Annual Rainfall $(\mathrm{mm})$ & 1100 \\
$\mathbf{6}$ & Daily minimum temperature $\left({ }^{\circ} \mathrm{C}\right)$ & 12.9 \\
\hline $\mathbf{7}$ & Daily maximum temperature $\left({ }^{\circ} \mathrm{C}\right)$ & 27.3 \\
\hline $\mathbf{8}$ & Soil type & Fluvisol \\
\hline $\mathbf{9}$ & Textural class & Clay loam \\
\hline $\mathbf{1 0}$ & pH(1:1 H2o) & 4.9 \\
\hline $\mathbf{1 1}$ & Total organic matter $(\%)$ & 4.60 \\
\hline $\mathbf{1 2}$ & Total nitrogen $(\%)$ & 0.35 \\
\hline $\mathbf{1 3}$ & Available phosphorous $(\mathrm{ppm})$ & 2.62 \\
\hline
\end{tabular}

Treatments \& Experimental design
Seed of Chloris gayana (CG) and Medicago sativa (MS) were mixed in a replacement manner $(75 \%(C G)+$ 
$25 \%(M S), 50 \%(C G)+50 \%(M S), 25 \%(C G)+75 \%(M S)$, $100 \%(C G)+25 \%(M S), 100 \%(C G)+50 \%(M S)$ and the pure stand of each species was also included for comparison purposes. The field design was a randomized complete block (RCBD) with three replication. The treatments were row planted in grass plots of $12 \mathrm{~m}^{2}$ \& net harvestable $(3 \mathrm{~m} \times 3 \mathrm{~m})$ area at $30 \mathrm{~cm}$ inter-row spacing method of sowing was in alternate row. The seed rates used were $15 \mathrm{~kg} / \mathrm{ha}$ for $C G \& 10 \mathrm{~kg} / \mathrm{ha}$ for $M S$. The base seeds for the two species were observed to be optimal for herbage production from the observations made earlier at Hawassa Agricultural Research Center. Using a sand paper to remove the external coat that may interfere uniform seed germination scarified the seed of $M S$ and also the germination percentages were taken $(86 \%$ and $72 \%$ for $M S$ and $C G$, respectively). The experimental plots were uniformly fertilized with DAP at planting at a rate of $100 \mathrm{~kg} / \mathrm{ha}$.

\section{Data collection and measurements}

\section{Dry matter yield}

Measurements taken before and after each harvest were plant height, forage dry mater yield and the relative yield (RY) and the relative total yield (RTY). Herbage biomass was cut from the middle 10 rows of the plots when the grass component reaches $50 \%$ flowering stage. The harvested biomass then separated in to grass and legumes. The weight of the total fresh biomass yield was recorded from each plot in the field and from each plot $500 \mathrm{~g}$ forage samples were taken, then oven dried for 72 hours at the temperature of $65^{\circ} \mathrm{C}$ to determine the dry matter content of the forages.

\section{Statistical Analysis:}

Differences among accessions were tested using analysis of variance (ANOVA) procedures of SAS general linear model (GLM) to compare treatment means (SAS, 2002). Least significance difference (LSD) at $5 \%$ significance level was used for comparison of means. The data for combined analysis, the following model was used: $Y i j k=\mu+A i+\beta j+e i j k$, Where, $Y i j k=$ the observation in $i^{\text {th }}$ treatment and $j^{\text {th }}$ block, $\mu=$ Over all mean, $\mathrm{Ai}=$ the $i^{\text {th }}$ treatment effect, $\beta \mathrm{j}=$ the $\mathrm{j}^{\text {th }}$ block effect and eijk $=$ the random error

\section{Calculation of interaction indices:}

The Dry matter yield of Chloris gayana grown in association with Medicago sativa (DMCG) \& MS growth with Chloris gayana (DMMS) in a replacement series mixture $(75 \% C G+25 \% M S, 50 \% \quad C G+50 M S$ and 25 CG+75\% MS, $100 \mathrm{CG}+25 \mathrm{MS}, 100 \mathrm{CG}+50 \mathrm{MS})$ were compared to those in their respective monoculture, Dry matter yield of Chloris gayana pure (DMCGp) and Dry matter yield of Medicago sativa pure (DMMSp) by calculating the relative yield (RY) of CG \& MS).

Ry $($ Chloris) $=$ DMCG (Mixture) $\div$ DMCGp (Pure) Ry $($ Medicago $)=$ DMMS (Mixture) $\div$ DMMSp (Pure) The relative yield total (RYT) was calculated according to the formula of Wit de (1960) and Begh (1968).

- $\mathrm{RYT}=\mathrm{Ry}$ (Chloris gayana) + Ry(Medicago sativa)

\section{RESULTS AND DISCUSSION}

The total dry matter yield (TDMY) of the species are given in Table2. Though mean TDMY values were not significantly different among the 75:25, 50:50, 25:75, 100:25 and 100:50CG:MS seed rate proportions, however higher TDMY was obtained in the 50:50 CG: MS seed proportion. Similar observations were reported by Frame (1986) and Schwank et al., (1986) in a grassclover mixed stand. Diriba (2001) also reported higher DM yields in a 50:50 seed mixtures of Panicum coloratum and stylosanthes mixtures.

Table 2: Total dry matter yields (t/ha) of Chloris gayana (CG) and Medicago sativa (MS) mixture in year 2003 \& 2004

\begin{tabular}{|c|c|}
\hline $\begin{array}{c}\text { Seed rate proportion } \\
\text { CG: } M S\end{array}$ & Mean dry matter yield (t/ha) \\
\hline $75: 25$ & 3.92 \\
\hline $50: 50$ & 4.44 \\
\hline $25: 75$ & 3.90 \\
\hline $100: 25$ & 3.97 \\
\hline $100: 50$ & \\
\hline Level of .Probability & Ns \\
\hline CV. & 30 \\
\hline
\end{tabular}

Relative yield (RY) of both species and relative yield total (RYT) are given in Table3. The treatment $50 \mathrm{CG}+50 \mathrm{Ms}$ and $100 \mathrm{CG}+50 \mathrm{MS}$ mean value of RYT were greater than one implying the presence of some yield advantage from the mixture treatments this suggests that the two species not were strictly 
competing for the same factor of growth. The higher yield advantage of 27 percent was obtained from the mixture treatment contributed CG $50 \%$ and MS $50 \%$ to the total seed mass of the mixture.

Table 3: Relative yields (t/ha) of Chloris gayana (CG) and Medicago sativa (MS) mixture in year 20003\&2004

\begin{tabular}{|l|l|l|l|}
\hline Treatments & $\begin{array}{l}\text { RYT } \\
2003\end{array}$ & $\begin{array}{l}\text { RYT } \\
2004\end{array}$ & $\begin{array}{l}\text { RYT } \\
\text { Combined }\end{array}$ \\
\hline $75: 25$ & 1.08 & 0.90 & 0.99 \\
\hline $50: 50$ & 1.39 & 1.14 & 1.27 \\
\hline $25: 75$ & 0.86 & 1.10 & 0.98 \\
\hline $100: 25$ & 0.93 & 0.83 & 0.88 \\
\hline $100: 50$ & 1.03 & 1.14 & 1.08 \\
\hline Level of. Prob. (0.50) & Ns & Ns & Ns \\
Cv. & 21 & 30 & 30 \\
& & & \\
\hline
\end{tabular}

The nutrition analysis result of crude protein (CP), Neutral detergent fiber (NDF), Acid detergent fiber (ADF), lignin and Digestible organic matter in dry matter (DOMD) are given in Table4. Thought mean NDF, ADF and DOMD value were not significantly different among the treatments, however mean $\mathrm{CP}$ and lignin values were highly significantly different among the treatments.

Table 4: Mean, CP, NDF, and ADF, Lignin and DOMD of Chloris gayana (CG) and Medicago sativa (MS) mixture at Hawassa

\begin{tabular}{|l|l|l|l|l|l|}
\hline $\begin{array}{l}\text { Seed rate } \\
\text { proportion } \\
\text { CG:MS }\end{array}$ & CP & NDF & ADF & Lignin & DOMD \\
\hline $1 . \quad 75: 25$ & 9.9 & 71.8 & 42.2 & 7.6 & 48.8 \\
\hline $2 . \quad 50: 50$ & 9.2 & 72.2 & 42.3 & 7.7 & 48 \\
\hline $3 . \quad 25: 75$ & 8.6 & 72.4 & 43.3 & 8 & 45.6 \\
\hline $4 . \quad$ Sole grass & 6.2 & 73.4 & 45 & 8.5 & 43.3 \\
\hline 5. Sole legume & 12.4 & 70.3 & 40 & 7 & 51.5 \\
\hline $6 . \quad 100: 25$ & 8.2 & 71.8 & 41.4 & 7.9 & 48.5 \\
\hline $7 . \quad 100: 50$ & 9.2 & 72.1 & 43 & 7.7 & 48.5 \\
\hline $\begin{array}{l}\text { Cv } \\
\text { Level sig. (0.05) }\end{array}$ & 19 & 2.4 & 5.9 & 5.8 & 7.1 \\
$* * *$ & Ns & Ns & Ns \\
\hline
\end{tabular}

\section{CONCLUSION AND RECOMMENDATIONS}

The results of this study showed that seed rate proportions of grass and legumes in mixtures affect dry matter yield, relative yield and relative yield totals of the legume and the grass component. From the aspect of higher dry matter yield and higher relative yield totals the $50 \%$ Chloris gayana and $50 \%$ Medicago sativa seed rate proportion could be considered optimal to develop balanced grass-legume mixed pastures. However; from this study alone it is not possible to determine the most appropriate combination of Chloris gayana and Medicago sativa seed that would optimize fodder yield and quality. More studies need to be undertaken under varying environments and harvesting strategies will be needed to fix seed proportions and develop management practice.

\section{ACKNOWLEDGEMENTS}

We would like to thank the Southern Agriculture Research Institute (SARI) for the financial support of this study.

\section{REFERENCES}

Begh, J.P. van den, 1968. Analysis of yield of grasses in mixture \& pure stand. Versal. Land bouwked on derz. 714: 1-71. Denbela H, Bizuayehu A and Mesifin M, 2015. Participatory On-Farm Evaluation and Demonstration of Improved Legume Forage Species in Benatsemay Woreda of South Omo 
Zone. Journal of Biology, Agriculture and Lemma Gizachew, Alemu Tadese and Abubeker Hassen Healthcare, Vol.5, No.21, 2015.

Daniel, K. (1989). Competitive Aspect of Grass-Legume mixtures with reference to field Experiment on Rhodes grass, lucence Mixture. In: Forage Network in Ethiopia. Newsletters No.21 ILCA, Addis Ababa.

Diriba Geleti, 2001. Panicum coloratum and stylosanthes guianensis mixed pasture under varying relative seed proportion of the component species: yield dynamics and inter component interaction during the year of establishment. ESAP (Ethiopian Society of animal production). 2002. Livestock in Food security Roles and Contributions Proceedings of 9th Annual Conference of (ESAP) held in Addis Ababa, Ethiopia, August 30-31, 2001. 433pp.

Droson, P.N (1976). Adapting species for forage mixture. In: multiple cropping. ASA special publication No. 21

Frames, J. and P. Newbould, 1986. Agronomy of white clover. Adv. Agron. 40:1-88.

Gethun Degu, Wilfered Mwangi,Tenaw workayehu and Bill Grisley (1991). Areka area mixed farming zone, Northern Omo Region Diagnostic survey. Research report No.15 IAR, Addis Ababa. IAR, 1988. Newsletter (1993). Botanical Composition, Improvement Intervention and Cattle Weight Gain of natural pasture of Western Ethiopia. Paper Presented During the seventh international Grass land Congress Held in Netherlands and Australia from 812 Feb. (1993).

Lulseged, G. 1985. The status of livestock, pasture and forage research and development in Ethiopia. Proceedings of the workshop held at Addis Ababa, Ethiopia, 8-10 January 1985. Institute of Agricultural Research, Addis Ababa, Ethiopia.

Mergia Abera. (2002). Hawassa Research Center, Progress Report, Year 2002

Raya Abagodu (1988). Sidama mixed farming zone, Diagnostic Survey. Research Report No. 3/88 IAR Addis Ababa.

Rhodes, Z. (1970) Competition between herbage grasses, as cited by, P.N. Drogom \& Smith (1976). Adapting species for forage Mixture P. 223-25 In: Multiple cropping, ASA special Publication No. 21.

Wit de C.T. 1960 on competition. Versl. Land bouwkd. On dert. 66.8: 1-82.

Cite this Article: Mergia A (2017). Biomass Yield and Biological Potential of Grass (Chloris gayana) and Legume (Medicago sativa) Mixtures under Variable Seed Rates in Southern Region of Ethiopia. Greener Journal of Agricultural Sciences, 7(6): 132-136, http://doi.org/10.15580/GJAS.2017.6.080817102. 